\title{
STUDIUM SKLENÍKOVÉHO JEVU PŘED 165 A 160 ROKY
}

\section{ZDENĚK SLANINA}

Tara centrum, Cukubská univerzita, Japonsko fromzdenek_s@yahoo.com

- https://doi.org/10.54779/chl20220065

Kvantitativnímu modelu role $\mathrm{CO}_{2} \mathrm{v}$ atmosféře vytvořenému ${ }^{1} v$ roce 1895 Svante Arrheniem předcházelo několik měření chování $\mathrm{CO}_{2}$ a dalších plynů pod vlivem slunečního či jiného světelného záření. Už před 165 lety, na výročním zasedání Amerického sdružení pro rozvoj vědy (American Association for the Advancement of Science, AAAS) v Albany ve státě New York, byl 23. srpna 1856 (v zastoupení) přednesen příspěvek ${ }^{2}$ od Eunice Foote(-ové) (1819-1888) nazvaný „Okolnosti ovlivňující teplo od slunečních paprsků“. Je zajímavé, že tomuto článku předchází rozsáhlejší text ${ }^{3}$, autorem kterého byl její manžel, soudce i vynálezce Elisha Foote. Manželův článek se obecněji věnuje měřní tepla od slunečních paprsků, nikoliv však ve vztahu k tomu, co se dnes nazývá skleníkový jev - tomu se výlučně věnovala jeho chot'. Tím o několik let předešla rigoróznější měření irského fyzika Johna Tyndalla (který sám navazoval na výsledky Fouriera, Pouilleta, i dalších). Leč její práce byla dlouho zapomenutá (až dodnes byla citována v tzv. uznávaných časopisech jen sedmkrát - vše rok 2019 nebo později), ač v ní na adresu $\mathrm{CO}_{2}$ prorocky uvedla, že jeho navýšení v ovzduší by nutně vedlo ke zvýšení atmosférické teploty. Eunice pracovala s válci (zřejmě skleněnými, žádné vyobrazení se ale nedochovalo) opatřenými teploměry, a také se vzduchovou pumpou. Nejprve z jednoho válce vzduch vyčerpala, zatímco druhý naopak natlakovala (byt' na samotné měření tlaku vybavena nebyla), a zjistila, že na slunečním světle dosahuje teplota ve válci s komprimovaným (ale jinak neupravovaným) vzduchem vyšších hodnot. Pak se posunula $\mathrm{k}$ pokusưm $\mathrm{s}$ dalšími plyny, $\mathrm{CO}_{2}$ a vodní párou, resp. vlhkým vzduchem. Při srovnávání vzduchu vysušeného $\mathrm{s}$ pomocí $\mathrm{CaCl}_{2}$ a vzduchu nasyceného vodní párou bylo $\mathrm{v}$ druhém případě dosaženo teploty o až $12^{\circ} \mathrm{F}$ vyšší (v Americe oblíbené stupně Fahrenheita). Ale $\mathrm{v}$ prrípadě $\mathrm{CO}_{2}$ byla dosažená teplota vyšší dokonce o $20^{\circ} \mathrm{F}$. Měření prováděla též pro vodík a kyslík, kde však nenašla podstatnější rozdíly oproti vzduchu. Tyto výsledky ji umožnily onu predikci, že př́padné navyšování obsahu $\mathrm{CO}_{2} \mathrm{v}$ atmosfére by nutně vedlo $\mathrm{k}$ růstu atmosférické teploty. $\mathrm{Z}$ dnešního pohledu se fakticky zabývala jen jednou komponentou energetiky skleníkového jevu - záŕením přicházejícím na Zemi od Slunce (druhou komponentou je záření emitované Zemí). Dnes je Eunice Foote považována za první osobu, která prokázala výraznou schopnost $\mathrm{CO}_{2}$ a vodní páry absorbovat energii slunečního záření, a nadto provedla propojení proměn složení atmosféry s klimatickými změnami. Mimochodem, o rok později došlo na její druhou ${ }^{4}$ a zřejmě poslední fyzikální práci, tentokrát o měření elektrického náboje lístkovým elektrometrem při stlačování či expanzi plynu. Je též označována za vůbec první Američanku, která publikovala odbornou fyzikální práci.

Tři roky po těchto jejích prvních, byt' jednoduchých, experimentech se tématu začal věnovat ${ }^{5}$ irský učenec John Tyndall (1820-1893) s o dost sofistikovanější aparaturou (obr. 1) - fakticky nezávisle, neb o nich zřejmě nevěděl. Tyndall během života pracoval na řadě problémů a jeho jméno dnes figuruje $v$ Tyndallově jevu ${ }^{6}$ týkajícím se rozptylu světla na různých č́sticích, $v$ tom počtu i na molekulách. Tyndallův jev pak podrobněji analyzoval ${ }^{7}$ Lord Rayleigh (původním jménem John Strutt; Nobelova cena za fyziku 1904). Rozptyl světla (často též zvaný Rayleighův rozptyl) je dnes užitečný při určování průměrné molekulové váhy polymerů. Svá pozorování o ohřevu atmosféricky významných plynů Tyndall sumarizoval ${ }^{8}$ před 160 lety ve své Bakerovské přednášce.

Tyndallova aparatura ${ }^{8}$ (obr. 1) na měření ohřivání různých plynů pohlcováním infračerveného záření používala jako zdroj toho záření nádoby $\mathrm{C}, \mathrm{C}^{\prime} \mathrm{s}$ horkou vodou, zahřívané plynovými kahany L, L'. Teplotu měřil pomocí termočlánku vyhodnocovaného galvanometrem viditelným uprostřed vyobrazení (termoelektrický jev pozoroval ${ }^{9}$ už Alessandro Volta v roce 1794). Tyndall fakticky pracoval se dvěma zdroji tepelného záření (tělesa $\mathrm{C}, \mathrm{C}^{\prime} \mathrm{s}$ vodou zahřivanou plynovými kahany), umístěnými na opačných stranách kovové trubice se zkoumaným plynem. Jeho nádoby $\mathrm{C}, \mathrm{C}^{\prime}$ tedy představovaly jistou realizaci absolutně černého tělesa. Trubice byla uzavřena plátky odštípnutými z krystalu soli kamenné. Jeho př́stroj by se mohl nazvat diferenční spektrometr (nebo i kalorimetrické měření absorpce záření). Rozdíly $\mathrm{v}$ záření produkovaném nádobou s horkou vodou při nebo bez průchodu trubicí se zkoumaným plynem umožňovala měřit dvě stínítka napojená přes termočlánky na galvanometr $-\mathrm{z}$ rozdílu $\mathrm{v}$ teplotách usuzoval na schopnost plynu absorbovat infračervené zárení. Během roku 1859 Tyndall takto proměřil devět různých plynů a dvacet různých par. Tak např́iklad zjistil, že suchý vzduch (zbavený $\mathrm{CO}_{2}$ ), kyslík, dusík či vodík znatelně neabsorbují. A výrazně $\mathrm{v}$ jeho pozorováních absorboval třeba ethylen nebo benzen. A také $\mathrm{CO}_{2}$ a vodní pára. Tedy neabsorbovaly diatomické molekuly s identickými atomy a absorbovaly víceatomové molekuly - v souhlase $s$ dnešními poznatky o vibrační spektroskopii (včetně vztahů mezi symetrií molekul a jejich infračervenými spektry) a skleníkových plynech. Tyndall své výsledky ve vztahu $\mathrm{k}$ atmosfére shrnul ${ }^{10}$ do věty: Atmosféra umožňuje vstup slunečního tepla, avšak kontroluje jeho výstup, a výsledkem je tendence akumulovat teplo na povrchu planety. Což dnes detailněji popisujeme v rámci skleníkového jevu 


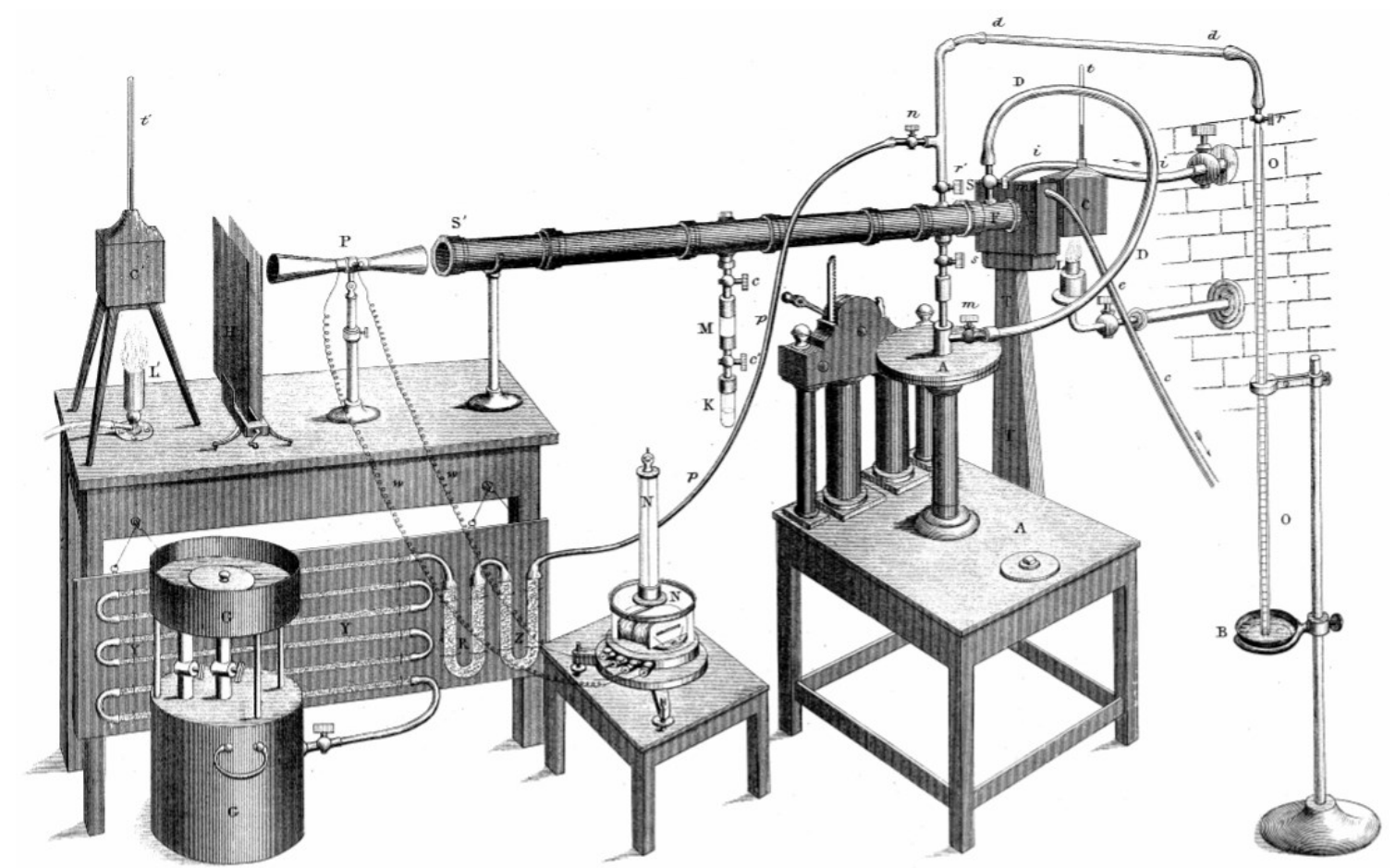

Obr. 1. Aparatura ${ }^{8}$ používaná Johnem Tyndallem pro měření absorpce infračerveného záření (produkovaného nádobou $\mathrm{C} s$ horkou vodou zahřívanou plynovým kahanem $\mathrm{L}$ ) různými plyny

s pomocí i infračerveného záření vyzařovaného z povrchu Země jako (nedokonalé) realizace absolutně černého tělesa o teplotě kolem $300 \mathrm{~K}$.

Zatímco Tyndall pracoval $\mathrm{s}$ infračerveným zářením, Eunice Foote jednoduše použivala celé spektrum slunečního záření dopadající na Zem. Její měření byla nutně méně přesná než výsledky, které získal Tyndall na svém diferenčním spektrometru. Vědecké bádání bylo $\mathrm{v}$ té době výrazně rozvinutější v Evropě než v Americe, a tak se americkým výsledkům ještě nedostávalo dostatečné pozornosti. $\mathrm{K}$ tomu přistupovaly obtíže $\mathrm{v}$ prrístupu $\mathrm{k}$ publikacím tištěným v Americe - a tak ji Tyndall, na rozdíl od francouzského matematika Fouriera, nezmiňuje. Dnes jsou všichni tři - Jean-Baptiste Joseph Fourier, Eunice Foote i John Tyndall - řazeni do galerie průkopníků výzkumů toho, co v současnosti představuje obrovský výzkumný komplex nazývaný skleníkový jev, ve kterém dnes roli hrají i mnohé další komponenty a procesy ${ }^{11-15}$. Tyndallovo jméno je zachováno nejen v rozptylu světla, ale pojmenovány jsou po něm ledovce, hory, ba i krátery na Měsíci a Marsu. A ve Velké Británii např. působí Tyndallovo centrum pro výzkum klimatické změny se sídlem ve východoanglickém městě Norwich.

\section{LITERATURA}

1. Slanina Z.: Chem. Listy 114, 701 (2020).

2. Foote E.: Am. J. Sci. Art. 22, 382 (1856).

3. Foote E.: Am. J. Sci. Art. 22, 377 (1856).

4. Foote E.: Am. J. Sci. Art. 24, 386 (1857).

5. Tyndall J.: Proc. Roy. Soc. 10, 37 (1859).

6. Tyndall J.: Phil. Trans. Roy. Soc. 160, 336 (1870).

7. Strutt J.: Phil. Mag. 41, 107 (1871).

8. Tyndall J.: Phil. Trans. Roy. Soc. 151, 1 (1861).

9. Volta A.: Ann. Chem. Natur. Hist. 5, 132 (1794).

10. Tyndall J.: Proc. Roy. Inst. 3, 155 (1859).

11. Vaida V., Daniel J. S., Kjaergaard H. G., Goss L. M., Tuck A. F.: Quart. J. Roy. Meteorol. Soc. 127, 1627 (2001).

12. Slanina Z., Uhlík F., Saito A. T., Ōsawa E.: Phys. Chem. Earth C 26, 505 (2001).

13. Klemperer W., Vaida, V.: Proc. Natl. Acad. Sci. U.S.A. 103, 10584 (2006).

14. Slanina Z., Uhlík F., Lee S.-L., Nagase S.: J. Quant. Spectrosc. Rad. Trans. 97, 415 (2006).

15. Vaida V.: J. Chem. Phys. 135, 020901 (2011).

- Slanina Z.: Chem. Listy 116, 65-66 (2022).

- https://doi.org/10.54779/chl20220065 